\title{
Historical institutional determinants of financial system development in Africa
}

\author{
CHUKWUNONYE O. EMENALO* \\ Lagos Business School, Pan-Atlantic University, Lagos, Nigeria \\ FRANCESCA GAGLIARDI** \\ Hertfordshire Business School, University of Hertfordshire, Hertfordshire, UK \\ GEOFFREY M. HODGSON ${ }^{* * *}$ \\ Hertfordshire Business School, University of Hertfordshire, Hertfordshire, UK
}

\begin{abstract}
The literature on the determinants of cross-country variation in financial system development identifies historical institutional factors, mostly rooted in colonial effects, as key causes. Using a sample of 39 African former European colonies for 2006-11, this paper investigates the extent to which the historical institutional determinants identified by legal origins, disease endowment, religion-based and ethnic fractionalisation theories explain current differences in financial system development across Africa. While most existing research focuses only on one financial system development dimension, namely financial system depth, this article considers also financial system access. The results do not support any of the above theories when depth measures are used, while three of them (legal origins, disease endowment and ethnic fractionalisation theories) are validated when using access measures. This suggests that in Africa financial system depth and access do not have common historical institutional determinants, pointing to the need for greater fine tuning of prevalent theories and empirical measures.
\end{abstract}

\section{Introduction}

Over the past 20 years, there has been renewed interest in the causes and consequences of financial system development. By financial system development this paper refers to how well a financial system fulfils its function of channelling financial resources from surplus units to those that need them for productive activities. ${ }^{1}$ In essence, if financial system A channels more financial resources to economic agents than financial system $\mathrm{B}$, then financial system $\mathrm{A}$ is more

\footnotetext{
*Email: cemenalo@lbs.edu.ng

**Email: f.gagliardi@herts.ac.uk

****Email: g.m.hodgson@herts.ac.uk

1 The financial system of a country is the system of banks, nonbank financial companies and financial markets in that country. This definition does not include systems of regulation and supervision. Keeping these distinct from financial systems is analytically useful to enable studying the effects of systems of regulation and supervision on financial system development.
} 
developed than B. Research suggests that the main function through which financial systems affect economic development is the channelling of savings to their best use, thereby improving resource allocation and productivity (Beck et al., 2011). In examining financial system development in African countries, the specific focus of the present study is on investigating how well financial systems in Africa channel pooled savings to entrepreneurs and firms in need of money for their business operations and growth. Consequently, financial system development measures that capture the volume of credit provided to the private sector (depth of the financial system) and the number of economic agents with access to finance (access to the financial system) are used in the empirical analysis conducted in this paper.

Financial system development has been found to be positively associated with economic development (Levine, 2005), although some studies have a more nuanced and mixed view (Andersen et al., 2012; Gries et al., 2009; Murinde, 2012), and more recent studies show an inverted-U relationship between financial system development and economic development (Arcand et al., 2015; Beck, 2013; Samargandi et al., 2015). Beck et al. (2014) find that it is the intermediation activities of the financial system, as measured by private credit by deposit money banks divided by gross domestic product (GDP), that matter for economic development in the long run, and not the overall size, as measured by gross value added of the financial sector as a percentage of GDP. Arcand et al. (2015: 141) show that 'there is a positive and robust correlation between financial depth and economic growth in countries with small and intermediate financial sectors, but ... there is a threshold (... around $80-120 \%$ of GDP) above which finance starts having a negative effect on economic growth'.

In Africa the average depth of the financial system (measured as private credit by deposit money banks over GDP) is $20.56 \%$, with South Africa being the only country with financial depth (measured as private credit by deposit money banks and other financial companies over GDP) above $80 \%$ (specifically $145.67 \%$ ). These figures put African countries behind other developing regions and suggest that financial system development in Africa is a problem that policy should address. In line with these points, Beck et al. (2011: 10) point out:

[W] hile financial development measured according to the ratio of private credit to GDP stood, on average, at 21 percent across Africa over the period 19802007, it was 32 percent in East Asia. During the same period, the East Asian economies grew 2.3 percent per year on average, while the African economies grew 0.7 percent on average.

Furthermore Beck et al. (2011: 12-13) note that:

the financial systems of Africa are significantly less sophisticated than systems elsewhere, and most are far from becoming overheated as several financial systems in Europe and North America did before the crisis. This does not mean that there is no fragility ... Nonetheless, most of the fragility in recent 
years has not arisen because of too much finance, but because of misallocated finance generated by governance challenges. In a nutshell, Africa's financial systems stand to gain significantly from deepening and broadening. If there is a decreasing marginal benefit from financial deepening or even a threshold where more financial deepening may have a negative effect, Africa's financial systems are far from reaching it.

Even if financial system development has no direct impact on economic development, recent research has shown that financial system development is positively associated with firm growth and performance (e.g. Ayyagari et al., 2008a; Beck et al., 2005; Beck and Demirguc-Kunt, 2006; Beck et al., 2008; Demirguc-Kunt et al., 2006), and with poverty alleviation (Beck et al. 2007; Hamori and Hashiguchi 2012). Consequently, financial system development has some desirable economic impact, and seeking to improve it by understanding its determinants, while at the same time managing its potential detrimental effects, is a worthy academic endeavour.

Since the seminal work of La Porta, Lopez-de-Silanes, Shleifer, and Vishny (e.g. La Porta et al., 1997, 1998), a related line of research, seeking to investigate the determinants of financial system development, identified historical institutional factors mostly rooted in colonial effects as key causes (Beck and Levine, 2005). These act as exogenous determinants of financial system development because they are neither current policy outcomes nor the result of current events, and they are not affected by current policy decisions of the countries under investigation.

This paper seeks to contribute to this growing line of enquiry by empirically investigating four theories that identify historical institutional determinants of cross-country variation in financial system development: legal origins theory, disease endowment theory, religion-based theory and ethnic fractionalisation theory. The analysis is carried out on a sample of 39 former European colonies in Africa for the period 2006-11. One of the distinguishing features of the study is that it uses two dimensions of financial system development: financial system depth, a size measure of financial systems, and financial system access, capturing access to finance by firms. Most previous research used financial system depth only but, given that financial systems are multidimensional, measures of size alone do not suffice (Cihak et al., 2013; World Bank, 2012). A second contribution of the work is that the above theories are tested across African countries using the latest financial system depth data, as well as updated and more current measures of historical institutional factors. Previous research by Honohan and Beck (2007) briefly discussed three of these theories but did not present regression results for Africa. On the other hand, Fowowe (2014) tested the legal origins theory for the African context but used measures of financial system depth only.

The empirical analysis does not find support for any of the theories of historical institutional determinants of cross-country variation in financial 
system development when size measures of financial systems alone are taken into account. By contrast, three theories (legal origins, disease endowment, and ethnic fractionalisation theories) are supported when access measures of financial systems are used. These findings suggest the need for greater fine tuning of the prevailing theories of historical institutional determinants of financial system development to understand why they affect financial system depth and access differently. Moreover, the results point to the need to take into account more relevant dimensions of financial system development in order to better understand its causes.

The remainder of the article is organised as follows. Section 2 offers a brief literature review of the theories of exogenous determinants of financial system development. Section 3 outlines the methodology, detailing the sample selection criteria, the variables included in the econometric models and the estimation method used. Section 4 reports the empirical results. Finally, Section 5 discusses the findings and their implications, and concludes.

\section{Literature review}

Four theories that identify historical institutional factors acting as determinants of cross-country variation in financial system development have been proposed in the literature (e.g. Ayyagari et al., 2008b; Beck et al., 2003; La Porta et al., 2008b; Stulz and Williamson, 2003): legal origins theory, disease endowment theory, religion-based theory and ethnic fractionalisation theory. These theories specify exogenous explanatory variables that are linked to the effects of colonisation and can explain cross-country variation in financial system development in former colonies. Arguably, they shed light on the origins of the institutions that may matter for financial system development and inform the worldviews that guide the design of institutions and sustain their durability over time.

\section{The legal origins theory}

La Porta et al. (2008b: 286) define legal origin as 'a style of social control of economic life (and maybe other aspects of life as well)'. The legal origins theory identifies the English common law legal origin, a strategy of social control seeking to support private market outcomes, and the French civil law legal origin, which instead seeks to replace private market outcomes with state-desired allocations. Beside affecting the development of laws and regulations, the organisation of the legal system and the formation of human capital of those in the legal system, these two organising strategies make up citizens' beliefs and values regarding the 'broad ideas of how the law and the state should work' (La Porta et al., 2008b: $307)$ and thus the best ways of organising economic activities.

La Porta et al. (2008b) contend that legal origins were transplanted to other countries through conquest and colonisation and, although over time there may be changes in the specific legal rules in former colonies, the reformed rules will 
be consistent with the relevant legal origin. Legal origins persist not only because they remain purely ideologies or cultures but also because they are embedded in laws, regulations, educational systems and human capital, and are transmitted from one generation to the next.

La Porta et al. (2008b) posit and show with a number of empirical findings that, compared to French civil law's legal origin, English common law's legal origin is associated with greater protection of contracting rights and private property rights, and with a greater level of contract enforcement, leading to greater financial contracting and financial system development. ${ }^{2}$ Shareholders and creditors have better protection in common law countries and this has positive consequences for financial system development.

Notwithstanding its theoretical insights and supporting empirical evidence, the legal origins theory has been criticised in terms of: (1) its conceptual arguments on the exogeneity of legal origin and the channels through which it affects legal rules and regulations, financial system development and other economic outcomes (Armour, Deakin, Lele et al., 2009; Armour, Deakin, Mollica et al., 2009); (2) its explanatory and forecasting power (Pistor, 2009); (3) its empirical methods (Armour, Deakin, Lele et al., 2009; Armour, Deakin, Mollica et al., 2009; Armour, Deakin, Sarkar et al., 2009; Pistor, 2009; Siems and Deakin, 2010; Spamann, 2010); (4) its validity for policy reforms (Armour, Deakin, Sarkar et al., 2009; Pistor, 2009). Moreover, Fowowe (2014) finds that legal origins do not explain cross-country variation in financial system depth in a sample of 39 African countries for 1996-2005.

\section{The disease endowment theory}

The disease endowment theory, as proposed by Acemoglu et al. (2001), also considers the impact of colonisers on the institutions developed in their colonies. It argues that the mortality rate facing would-be colonisers is the key exogenous variable explaining cross-country variation in current institutions and, consequently, current economic outcomes. In this framework 'it is not the identity of the colonizer or legal origin that matters, but whether European colonialists could safely settle in a particular location: where they could not settle, they created worse institutions' (Acemoglu et al., 2001: 1373, emphasis added). In essence, where colonisers did not settle, they set up extractive institutions that did not protect private property rights and did not countervail the expropriation of resources by governments. On the other hand, where colonisers settled, institutions that protected private property rights and checked government power were set up. These colonial-time institutions persisted after independence and

2 Common law countries have better financial system development than French civil law countries because their regulation strategies are focused on sustaining rather than replacing markets, thus encouraging greater financial contracting (La Porta et al., 2008b). 
guided the formation of current institutions that determine current economic outcomes in former colonies. ${ }^{3}$

Using a global sample of former European colonies, Beck et al. (2003) find empirical support for a robust relationship between initial disease endowments and financial system development: former colonies that did not have environments favourable to the settlement of European colonisers have less developed financial systems. Applying the disease endowment theory to the African case, the prevalence and stability of malaria in tropical areas appear to have been unfavourable to early European settlers, possibly leading to the formation of extractive institutions (Acemoglu et al., 2001). Consequently, African countries in geographic areas prone to malaria should be expected to have inherited institutions that are detrimental to economic outcomes such as financial system development.

\section{The religion-based theory}

Religion has been argued to affect economic activities and economic outcomes (McCleary and Barro, 2006). ${ }^{4}$ In these religion-based arguments, religion is a source of values, beliefs, worldviews, moral norms and legal rules expected to guide human behaviour and attitudes in different activities, including economic ones (McCleary and Barro, 2006; Stulz and Williamson, 2003). As Beck et al. (2003: 151) put it, 'many scholars argue that religion shapes national views regarding property rights, competition, and the role of the state'.

Arrunada (2010) evaluates Catholicism and Protestantism to identify their relative contribution to behaviours and attitudes that affect economic activities. He tests a work ethic hypothesis, arguing that Protestants work more than Catholics, and a social ethic hypothesis, which contends that Protestants exert more mutual social control, support legal institutions and institutional enforcement more strongly, and hold more homogeneous values than Catholics. ${ }^{5}$ Arrunada (2010: 908) finds empirical support only for the social ethic hypothesis, and states that 'with its relatively more homogeneous standards, Protestantism seems better adapted [than Catholicism] for impersonal trading between anonymous parties, such as those in commerce, finance and industry'.

3 Acemoglu et al. (2002) focus on the effects of the policies that Europeans pursued during colonisation on the future economic prosperity of colonies, as proxied by urbanisation patterns and population density. The core argument here is that Europeans tended to introduce institutions encouraging investment in poor regions; this promoted their economic development, while at the same time depressing rich regions. In their view 'This reversal weighs against a view that links economic development with geographic factors' (Acemoglu et al., 2002: 1231). Testing the validity of this proposition in the African context is beyond the scope of the present paper, but is nonetheless an issue that future research should address.

4 Max Weber's seminal work proposed the Protestant ethic arguments and its effects on the emergence of capitalism in Western Europe (Weber, 2005 [1930]).

5 The social ethic hypothesis has three dimensions: social control, rule of law and homogeneous values. 
Stulz and Williamson (2003) find strong effects of religion on debt markets, banking development and the quality of creditor rights protection, with countries where Catholicism is the dominant religion having weaker creditor rights protection and weaker enforcement of rights than countries where the dominant religion is Protestantism. Consequently, based on the foregoing arguments and results of Arrunada (2010), and Stulz and Williamson (2003), countries dominated by Protestantism should have higher levels of financial system development than those dominated by Catholicism.

La Porta et al. (1999) argue that countries where Catholicism and Islam are the dominant religions have more government intervention, as evidenced by worse protection of property rights and regulation, than countries where Protestantism is the prevailing religion. They contend that Catholicism and Islam are used for political purposes in a way that undermines the development of markets and that this negative impact is stronger in countries where Islam is the dominant religion. Hence, based on this reasoning, countries with a majority adhering to Islam or Catholicism should have lower financial system development on average than countries with a majority adhering to Protestantism. ${ }^{6}$

\section{The ethnic fractionalisation theory}

The ethnic fractionalisation theory posits that ethnic fractionalisation makes a country more socially polarised, with negative consequences for private contracting and hence for financial system development. Social polarisation makes it difficult to adopt growth-enhancing policies, to reach consensus on social and public goods, to choose infrastructures that promote economic growth (Easterly and Levine, 1997; Easterly et al., 2006) and to develop institutions that provide a level playing field for economic activities among the members of a society.

In the context of weak, ineffective or corrupt state legal systems, ethnic divisions may promote more intra-ethnic transactions based on kinship ties and reputation (Carr and Landa, 1983; Greif, 1992, 1993; Landa, 1981) rather than inter-ethnic transactions based on effective legal institutions and enforcement systems. The predominance of these intra-ethnic transactions may limit private markets, credit and financial contracting between economic agents (Cooter and Landa, 1984; Greif et al., 1994), with negative consequences for financial system development.

La Porta et al. (1999) show that more ethnically diverse countries have lower quality institutions, lower quality policies, lower quality infrastructure and lower quality public goods. Beck et al. (2003: 151) note that 'when this view [ethnic fractionalisation theory] is applied to the financial sector, the implication is clear: greater ethnic diversity implies the adoption of policies and institutions that are

6 La Porta et al. (1999)'s grouping of Catholicism with Islam seems simplistic in the light of literature showing that Catholicism and Protestantism align towards separation between the spiritual and temporal power more than Islam does (Fox, 2006; Philpott, 2007). 
focused on maintaining power and control, rather than on creating an open and competitive financial system'.

In the context of African countries, present-day ethnic fractionalisation can be seen as exacerbated by colonisation, which led to the creation of artificial borders enclosing disparate ethnic groups in each country. Easterly and Levine (1997: 1213) note that 'the borders of African nations were determined through a tragicomic series of negotiations between European powers in the nineteenth century that split up ethnic groups and exacerbated pre-existing high levels of ethnic and linguistic diversity'. Based on this observation and the preceding arguments, the empirical work carried out in this paper tests whether ethnic fractionalisation has an adverse impact on financial system development in African countries.

\section{Empirical question and methodology}

This work empirically investigates the above-discussed theories, which identify the historical institutional determinants of cross-country variation in financial system development: legal origins theory, disease endowment theory, religionbased theory and ethnic fractionalisation theory. The analysis focuses on the African continent, which offers a fascinating context for analysis. African countries form a group of recently independent former colonies, mainly British and French, and hence are an ideal context to test the legal origins theory. The colonial experience of former European colonies in Africa can justify the argument that legal origin is exogenous to these countries (La Porta et al., 2008b). Second, the conduciveness of Africa to malaria (e.g. Kiszewski et al., 2004; Sachs and Chambers, 2009) makes it a good context to examine the disease endowment theory as Africa may have significantly affected colonisers' settlement strategies due to its fatal disease environment. Third, some religious beliefs in present-day African countries can be attributed mainly to the influence of European colonisers. Christianity, as well as Islam, can be viewed as an exogenous source of worldviews in the African countries where these religions are practised. Lastly, given that African countries are the most ethnically fractionalised (Alesina et al., 2003), ethnic fractionalisation may manifest its greatest economic effects in these countries.

A further set of issues that make Africa a suitable context to carry out the study proposed in this paper is related to the fact that its countries share some distinguishing features in terms of scale (i.e. low GDP, low GDP per capita and sparse population), informality (i.e. the existence of large informal sectors), governance problems in the private and public sectors, and shocks (i.e. conflicts, famine, economic and politico-societal meltdowns) (Honohan and Beck, 2007). These features make it reasonable to treat African countries as relatively homogeneous along the above-mentioned social, economic, political and institutional dimensions (as compared to countries in other continents) and 
yet sufficiently heterogeneous in the key dimensions of interest in this paper to enable cross-country comparison.

To maintain the exogenous nature of the postulated key explanatory variables of the theories of institutional determinants of cross-country variation in financial system development, the empirical analysis focuses only on African countries that were former European colonies. Besides excluding countries that were never colonised by Europeans, countries for which data were missing have also been excluded. Given these two sample selection criteria, the sample employed in the empirical analysis consists of 39 countries. $^{7}$

The period of study is from 2006 to 2011 . These years were chosen because, at the time of writing the paper, measures of financial system access for African countries were available up to 2011 starting from $2006 .{ }^{8}$ For financial system depth measures, data for all the six years included in the sample period are available for 36 of the 39 sample countries, while the remaining three countries have three, four and five years of data respectively. As far as data on the chosen financial system access measures are concerned, for nine countries these data are available for two years in the 2006-11 period, and for 30 countries only one year of data is available. Given these issues, the data were averaged over the period from 2006 to 2011 for the 39 sample countries and this generated a cross-section of 39 observations.

The following subsections present the measures of financial system development and the historical institutional variables, and discuss the other variables included in the empirical specification, as well as the econometric strategy adopted. All the variables, including their definition, source and the previous works that have used them, are summarised in Table 1.

\subsection{Measuring financial system development}

Research suggests that the main function through which financial systems affect economic development is the channelling of a society's savings to their best use, thereby improving resource allocation and productivity (Beck et al., 2011). Hence, the present study uses financial system development measures that try to capture the intermediation role of financial systems, especially proxies related to the volume and spread of credit intermediated through the banking system. This is an appropriate choice given that in Africa the financial system is dominated by the banking sector and only a few countries have organised equity markets (Beck et al., 2011).

Direct empirical measures of financial system development are not yet available. For this reason researchers have been using size measures of financial systems as proxies of financial system development, especially measures of financial system depth (Beck et al., 2010). In line with the literature, depth

7 See Appendix 1 for the full list of countries included in the sample.

8 In some cases these measures became available only in 2011. 
Table 1. Variables: definition, measurement, sources and usage

\begin{tabular}{|c|c|c|}
\hline Variable & Definition & $\begin{array}{l}\text { Source and, where } \\
\text { available, published } \\
\text { works that have used } \\
\text { the variable }\end{array}$ \\
\hline \multicolumn{3}{|c|}{ Financial system depth and access variables } \\
\hline $\begin{array}{l}\text { Private credit by deposit } \\
\text { money banks on GDP } \\
(\mathrm{DMB})\end{array}$ & $\begin{array}{l}\text { Private credit by deposit money banks/GDP (ratio in } \\
\% \text { ). This variable measures the ratio of claims on } \\
\text { the private sector by deposit money banks to } \\
\text { GDP. It does not distinguish deposit money banks } \\
\text { based on their ownership types and does not } \\
\text { include securitised loans (Beck et al., 2010: } 81 \text { ). } \\
\text { Data are from } 2006 \text { to } 2011 \text {. }\end{array}$ & $\begin{array}{l}\text { Source: Beck et al. } \\
\text { (2013) }\end{array}$ \\
\hline $\begin{array}{l}\text { Private credit by deposit } \\
\text { money banks and } \\
\text { other financial } \\
\text { companies on GDP } \\
\text { (DMBOFI) }\end{array}$ & $\begin{array}{l}\text { Private credit by deposit money banks and other } \\
\text { financial companies/GDP (ratio in \%). This } \\
\text { variable measures the ratio of claims on the } \\
\text { private sector by deposit money banks and other } \\
\text { financial companies to GDP (Beck et al., 2010: } \\
\text { 81). Data are from } 2006 \text { to } 2011 \text {. }\end{array}$ & $\begin{array}{l}\text { Source: Beck et al. } \\
\qquad \begin{array}{l}\text { (2013) } \\
\text { Published works: } \\
\text { Beck et al. (2013); } \\
\text { Djankov et al. (2007) }\end{array}\end{array}$ \\
\hline $\begin{array}{l}\text { Firms with a bank loan } \\
\text { or line of credit } \\
\text { (FWLOC) }\end{array}$ & $\begin{array}{l}\text { Percentage of firms in a country with a bank loan or } \\
\text { a line of credit. This measures the 'percentage of } \\
\text { firms in the formal sector with a line of credit or a } \\
\text { loan from a formal financial institution, such as a } \\
\text { bank, credit union, microfinance institution, or } \\
\text { cooperative' (World Bank, 2013). Data are from } \\
2006 \text { to } 2011 \text {. }\end{array}$ & $\begin{array}{l}\text { Source: World Bank } \\
\text { (2013) }\end{array}$ \\
\hline $\begin{array}{l}\text { Firms with finance } \\
\text { constraints } \\
\text { (FWAFMC) }\end{array}$ & $\begin{array}{l}\text { Percentage of firms in a country that identify access } \\
\text { to finance as a major constraint to business } \\
\text { operations. This measures the 'percentage of } \\
\text { firms identifying access/cost of finance as a } \\
\text { "major" or "very severe" obstacle' (World Bank, } \\
\text { 2013). Data are from } 2006 \text { to } 2011 \text {. } \\
\text { Historical institutional variables }\end{array}$ & $\begin{array}{l}\text { Source: World Bank } \\
\text { (2013) }\end{array}$ \\
\hline $\begin{array}{l}\text { French legal origin } \\
\qquad(\text { FLO })\end{array}$ & $\begin{array}{l}\text { 'A dummy variable that identifies the legal origin of } \\
\text { the company law or commercial code of each } \\
\text { country. The five origins are English, French, } \\
\text { German, Nordic, and Socialist' (Djankov et al., } \\
2007: 304 \text { ). The dummy variable takes the value } \\
\text { of } 1 \text { for countries categorised as part of the } \\
\text { French legal origin family and } 0 \text { otherwise. }\end{array}$ & $\begin{array}{l}\text { Source: La Porta et al. } \\
\text { (2008a) } \\
\text { Published works: } \\
\text { Djankov et al. } \\
\text { (2007); La Porta et al. } \\
\text { (2008b) }\end{array}$ \\
\hline $\begin{array}{l}\text { Malaria stability index } \\
\quad(\mathrm{MSI})\end{array}$ & $\begin{array}{l}\text { The malaria stability index 'combines climatic } \\
\text { factors and biological properties of the regionally } \\
\text { dominant malaria vector into an index of the } \\
\text { stability of malaria transmission', and 'is } \\
\text { measured on a highly disaggregated subnational } \\
\text { level and then averaged for the entire country' } \\
\text { (Carstensen and Gundlach, 2006: 335). Details of } \\
\text { the construction of the index are given in } \\
\text { (Carstensen and Gundlach, 2006; Kiszewski } \\
\text { et al., 2004). }\end{array}$ & $\begin{array}{l}\text { Source: McCord (2012) } \\
\text { Published works: } \\
\text { Carstensen and } \\
\text { Gundlach (2006), } \\
\text { Gennaioli et al. } \\
\text { (2014), Sachs (2003) }\end{array}$ \\
\hline
\end{tabular}


Table 1. (Continued)

\begin{tabular}{|c|c|c|}
\hline Variable & Definition & $\begin{array}{l}\text { Source and, where } \\
\text { available, published } \\
\text { works that have used } \\
\text { the variable }\end{array}$ \\
\hline Catholicism (CAT) & $\begin{array}{l}\text { A dummy variable that takes the value of } 1 \text { if } \\
\text { Catholics are the dominant religious group in a } \\
\text { country and } 0 \text { otherwise. }\end{array}$ & $\begin{array}{l}\text { Source: authors' coding } \\
\text { based on the } \\
\text { percentage of } \\
\text { religious groups in } \\
\text { different countries as } \\
\text { given in La Porta } \\
\text { et al. (1999) }\end{array}$ \\
\hline Islam (ISLAM) & $\begin{array}{l}\text { A dummy variable that takes the value of } 1 \text { if } \\
\text { Muslims are the dominant religious group in the } \\
\text { country and } 0 \text { otherwise. }\end{array}$ & $\begin{array}{l}\text { Source: authors' coding } \\
\text { based on the } \\
\text { percentage of } \\
\text { religious groups in } \\
\text { different countries as } \\
\text { given in La Porta } \\
\text { et al. (1999) }\end{array}$ \\
\hline Other religions (OTHR) & $\begin{array}{l}\text { A dummy variable that takes the value of } 1 \text { if the } \\
\text { dominant religious group in the country is from a } \\
\text { religion other than Protestantism, Catholicism, } \\
\text { and Islam, and } 0 \text { otherwise. }\end{array}$ & $\begin{array}{l}\text { Source: authors' coding } \\
\text { based on the } \\
\text { percentage of } \\
\text { religious groups in } \\
\text { different countries as } \\
\text { given in La Porta } \\
\text { et al. (1999) }\end{array}$ \\
\hline $\begin{array}{l}\text { Ethnic fractionalisation } \\
\text { index }(\mathrm{EF})\end{array}$ & $\begin{array}{l}\text { 'This variable indicates the probability that two } \\
\text { randomly selected individuals in a country are not } \\
\text { from the same ethnic group' (Ayyagari et al., } \\
\text { 2008b: 1869). Higher values of the variable imply } \\
\text { higher ethnic fractionalisation in a given country. } \\
\text { Control variables }\end{array}$ & $\begin{array}{l}\text { Source: Alesina et al. } \\
\text { (2003) } \\
\text { Published works: } \\
\text { Ayyagari et al. } \\
\text { (2008b) }\end{array}$ \\
\hline GDP per capita (GCAP) & $\begin{array}{l}\text { Natural logarithm of the annual GDP per capita } \\
\text { based on purchasing power parity (PPP). PPP } \\
\text { GDP is gross domestic product converted to } \\
\text { international dollars using purchasing power } \\
\text { parity rates. An international dollar has the same } \\
\text { purchasing power over GDP as the US dollar has } \\
\text { in the United States. GDP at purchaser's prices is } \\
\text { the sum of gross value added by all resident } \\
\text { producers in the economy plus any product taxes } \\
\text { and minus any subsidies not included in the value } \\
\text { of the products. Data are in constant } 2011 \\
\text { international dollars (World Bank, 2014a, series } \\
\text { NY.GDP.PCAP.PP.KD definition). Data available } \\
\text { from } 2006 \text { to 2011. }\end{array}$ & $\begin{array}{l}\text { Source: World Bank } \\
\qquad \begin{array}{l}\text { (2014a) } \\
\text { Published works: } \\
\text { Armour, Deakin, } \\
\text { Sarkar et al. (2009); } \\
\text { La Porta et al. } \\
\text { (2008b) }\end{array}\end{array}$ \\
\hline
\end{tabular}


Table 1. (Continued)

\begin{tabular}{|c|c|c|}
\hline Variable & Definition & $\begin{array}{l}\text { Source and, where } \\
\text { available, published } \\
\text { works that have used } \\
\text { the variable }\end{array}$ \\
\hline Inflation (INFL) & $\begin{array}{l}\text { Inflation as measured by the annual growth rate of } \\
\text { the GDP implicit deflator. The GDP implicit } \\
\text { deflator is the ratio of GDP in current local } \\
\text { currency to GDP in constant local currency } \\
\text { (World Bank, 2014a, series } \\
\text { NY.GDP.DEFL.KD.ZG definition). The values } \\
\text { are in \% and available for the years } 2006-11 .\end{array}$ & $\begin{array}{l}\text { Source: World Bank } \\
\text { (2014a) } \\
\text { Published work: } \\
\text { Djankov et al. (2007) }\end{array}$ \\
\hline $\begin{array}{l}\text { WG political stability } \\
\text { (PS) }\end{array}$ & $\begin{array}{l}\text { WG political stability captures 'perceptions of the } \\
\text { likelihood that the government will be } \\
\text { destabilised or overthrown by unconstitutional or } \\
\text { violent means, including politically-motivated } \\
\text { violence and terrorism' (Kaufmann et al., } 2010 \text { : } \\
\text { 4). Its values range from approximately }-2.5 \text { to } \\
\text { 2.5, with higher values signifying more political } \\
\text { stability. Data from } 2006 \text { to } 2011 \text {. }\end{array}$ & $\begin{array}{l}\text { Source: World Bank } \\
\text { (2014b) }\end{array}$ \\
\hline Population density (PD) & $\begin{array}{l}\text { Population density is midyear population divided by } \\
\text { land area in square kilometres (World Bank, } \\
2014 \text { a, series EN.POP.DNST definition). Data } \\
\text { from } 2006 \text { to } 2011 \text {. }\end{array}$ & $\begin{array}{l}\text { Source: World Bank } \\
\qquad(2014 a)\end{array}$ \\
\hline $\begin{array}{l}\text { WG control of } \\
\text { corruption (CC) }\end{array}$ & $\begin{array}{l}\text { The WG control of corruption indicator measures } \\
\text { 'perceptions of the extent to which public power } \\
\text { is exercised for private gain, including both petty } \\
\text { and grand forms of corruption, as well as } \\
\text { "capture" of the state by elites and private } \\
\text { interests' (Kaufmann et al., } 2010: 4 \text { ). Its values } \\
\text { range from approximately }-2.5 \text { to } 2.5 \text {, with } \\
\text { higher values signifying higher institutional } \\
\text { quality. Data from } 2006 \text { to } 2011 \text {. }\end{array}$ & $\begin{array}{l}\text { Source: World Bank } \\
\qquad(2014 \mathrm{~b}) \\
\text { Published works: La } \\
\text { Porta et al. }(2008 \mathrm{~b})\end{array}$ \\
\hline Trade openness & $\begin{array}{l}\text { Trade openness is 'the sum of exports and imports } \\
\text { of goods and services measured as a share of } \\
\text { gross domestic product' (World Bank, 2014a, } \\
\text { series NE.TRD.GNFS.ZS definition). Data from } \\
2006 \text { to } 2011 \text {. }\end{array}$ & $\begin{array}{l}\text { Source: World Bank } \\
\qquad(2014 \mathrm{a})\end{array}$ \\
\hline
\end{tabular}

Note: The taxonomy has been drawn from the literature discussed in Section 3.2 and the variables presented in Sections 3.1-3.3.

Country-level averages for the variables included in this table are reported in Table 2.

measures (volume of credit provided to the private sector) are used as proxies of financial system development also in this study. A novel contribution of this paper is that it uses also measures of financial system access, capturing access to finance by firms (Cihak et al., 2013; World Bank, 2012). This is done in order to account for two key dimensions of financial systems and, consequently, attempt 
to get a better understanding of financial system development in relation to its firm financing function.

Two financial system depth variables are included in the econometric model. These are the ratio of private credit by deposit money banks over GDP (hereafter $\mathrm{DMB}$ ) and the ratio of private credit by deposit money banks and other financial companies over GDP (hereafter DMBOFI). DMB measures the volume of credit from banks to the private sector (Beck et al., 2010), while DMBOFI measures the volume of credit to the private sector from banks and sources other than financial markets (e.g. Beck, Demirguc-Kunt and Levine, 2003, 2010; Beck, Demirguc-Kunt and Maksimovic, 2006; Djankov et al., 2007). Higher levels of DMB and DMBOFI are associated with larger volumes of credit intermediated to the private sector and hence higher financial system development. As far as financial system access is concerned, this is measured using two variables that are collected through the Enterprise Surveys of the World Bank and are available through the Global Financial Development Database (GFDD). The first one is the percentage of firms in a country with a bank loan or a line of credit (hereafter FWLOC). ${ }^{9}$ Higher levels of FWLOC mean higher levels of access to finance by firms and hence higher financial system development. The second measure of financial system access is the percentage of firms in a country that identify access to finance as a major constraint to business operations (hereafter FWAFMC). ${ }^{10}$ Higher levels of FWAFMC imply less access to finance by firms and hence lower financial system development.

\subsection{Measuring historical institutional variables}

A country's legal origin is measured with a dummy variable labelled 'French legal origin', which takes the value of 1 for countries categorised as French civil law and 0 otherwise, based on the data provided by La Porta et al. (1999) and La Porta et al. (2008a). The base (and omitted) group for this dummy variable is the 'English legal origin' group, which includes countries categorised as English/British common law. Of the 39 former European colonies in Africa that make up the full sample, 25 are classified as French legal origin, while 14 are classified as English legal origin.

To test the hypothesis related to the disease endowment theory, measures of the disease endowment of African former European colonies are required. The settler mortality rates of Acemoglu et al. (2001) are not available for all the African countries included in the full sample. Hence a challenge lies in identifying variables that can help proxy for potential death risks from dangerous diseases

9 As defined in the GFDD, this variable measures the percentage of firms in the formal sector with a line of credit or a loan from a formal financial institution, such as a bank, credit union, microfinance institution or cooperative (World Bank, 2013).

10 Studies have shown that lack of access to finance hinders firm growth, particularly for SMEs (e.g., Beck et al., 2005; Beck and Demirguc-Kunt, 2006). 
for European colonisers. This paper uses the 'malaria stability index' (MSI). ${ }^{11}$ Developed by Kiszewski et al. (2004), this exogenous variable has been used in the economic development literature (e.g. Carstensen and Gundlach, 2006; Gennaioli et al., 2014; Sachs, 2003), but does not seem to have been used much in the financial development literature. Based on the hypothesis related to the disease endowment theory, the MSI is expected to be negatively associated with financial system development because there is a higher malaria burden at higher values of the index. ${ }^{12}$

To measure the effect of religion, following Stulz and Williamson (2003), three dummy variables are defined to proxy the religious affiliation of the majority of the population in each country, based on the data on religious affiliation developed by La Porta et al. (1999). These are: 'Catholicism', 'Islam', and 'Other religions'; the omitted (and base) group is Protestantism. 'Catholicism' is a dummy variable that takes the value of 1 if the religious affiliation of the majority of the population in a country is Catholicism and 0 otherwise. 'Islam' is a dummy variable that takes the value of 1 if the religious affiliation of the majority of the population in a country is Islam and 0 otherwise. The 'Other religions' dummy variable takes the value of 1 if the religious affiliation of the majority of the population in a country is neither Catholicism, Islam nor Protestantism and 0 otherwise. In the sample, there are 9 countries in the 'Catholicism' group, 12 in the 'Islam' group, 15 in the 'Other religions' group, and 3 in the 'Protestantism' group.

Finally, the updated ethnic fractionalisation index (EF) compiled by Alesina et al. (2003) is employed to measure the effect of ethnic fractionalisation on financial system development. Alesina et al. (2003) argue that their updated ethnic fractionalisation index is based on a broader measure of ethnicity, which goes beyond language to include racial characteristics, such as skin colour and racial origin, and is constructed to cover a broader cross-section of countries.

\subsection{The econometric specification}

As mentioned in Section 3.1, the dependent variables used in the empirical models are proxies of financial system development, namely measures of both financial system depth and access. Historical institutional variables are instead the main

11 The MSI was constructed from biological and climatic variables in a way that makes it an exogenous measure of malaria-endemic geographic areas. Kiszewski et al. (2004: 486) state that this index was developed 'based on the most powerful intrinsic properties of anopheline mosquito vectors of malaria that interact with climate to determine vectorial capacity. Because this index [the MSI] examines potential transmission stability, it includes regions where malaria is not currently transmitted, but where it had been transmitted in the past or where it might be transmitted in the future.'

12 It is important to note that the MSI does not measure current malaria fatalities or infections, but only proxies for geographical areas and climates in Africa that have always posed a lethal threat to human beings by being conducive to malaria infection and transmission. Hence the MSI seems to be an appropriate proxy for the malaria disease endowment that the European colonisers encountered during colonisation, which may have affected their colonisation strategies. 
explanatory variables (see Section 3.2). The vector of other regressors includes the following variables. GDP per capita is used to control for demand-side factors as it has been shown that countries with higher incomes may more easily drive demand for financial system services, with positive consequences for financial system development (Djankov et al., 2007; La Porta et al., 2008b). A variable measuring inflation is included to control for macroeconomic stability given that inflation is argued to affect financial system development (e.g. Djankov et al., 2007; Honohan and Beck, 2007). Furthermore, to control for political stability, a Worldwide Governance Indicator called the 'political stability and absence of violence/terrorism' indicator (hereafter WG political stability) is included in the econometric model. WG political stability captures 'perceptions of the likelihood that the government will be destabilized or overthrown by unconstitutional or violent means, including politically-motivated violence and terrorism' (Kaufmann et al., 2010: 4). The WG political stability has been designed to range between approximately -2.5 and 2.5 , with higher values indicating higher levels of political stability in a country. ${ }^{13}$

Population density is argued to affect financial system development in Africa (Beck et al., 2011) and is also included in the estimated models. We control for overall institutional quality by including the corruption indicator of the Worldwide Governance Indicators (hereafter WG control of corruption). The WG control of corruption measures the level of corruption in a country, which is one of the three main areas of governance identified by Kaufmann et al. (2010: 4) that have to do with 'the respect of citizens and the state for the institutions that govern economic and social interactions among them'. The WG control of corruption has been designed to range between approximately -2.5 and 2.5, with higher values indicating better institutional quality. ${ }^{14}$ Finally, we control for trade openness using the sum of exports and imports as a percentage of GDP. ${ }^{15}$

The econometric specification is estimated using the Ordinary Least Squares (OLS) method. This is because, given the relatively time-invariant nature of the historical institutional variables used, which leaves little, if any, withincountry variation in the sample, the econometric strategy exploits betweencountry variation in the explanatory variables. To this end, the data are averaged over the six-year period 2006-11 to obtain a cross-section of 39 former European colonies in Africa. Given this new data structure, the OLS method is best suited to estimate the effects of historical institutional variables on

13 For details on the construction of the WG political stability index see Kaufmann et al. (2010).

14 For details on the construction of the WG control of corruption index see Kaufmann et al. (2010).

15 We owe the suggestion of including WG control of corruption and trade openness in the empirical models to an anonymous referee. The same referee has also pointed out that the level of remittances has been found to be an important variable by other studies. However, in the context of the present paper this variable (whether measured in levels or in natural logarithm) was not statistically correlated with any of the dependent variables employed. Therefore, remittances have not been included in the empirical models to save degrees of freedom, given the limited number of observations at hand. 
Table 2. Summary statistics

\begin{tabular}{|c|c|c|c|c|c|}
\hline Variable & Observations & Mean & Std. dev. & Minimum & Maximum \\
\hline $\begin{array}{l}\text { Private credit by deposit money banks on } \\
\text { GDP (DMB)* }\end{array}$ & 39 & 20.65 & 18.76 & 3.32 & 77.80 \\
\hline $\begin{array}{l}\text { Private credit by deposit money banks } \\
\text { and other financial companies on GDP } \\
\text { (DMBOFI)* }\end{array}$ & 39 & 22.66 & 26.23 & 3.32 & 145.67 \\
\hline $\begin{array}{l}\text { Firms with a bank loan or line of credit } \\
\text { (FWLOC)* }\end{array}$ & 39 & 22.61 & 12.11 & 2.80 & 47.40 \\
\hline $\begin{array}{l}\text { Firms with finance constraints } \\
\text { (FWAFMC)* }\end{array}$ & 39 & 46.15 & 14.66 & 15.50 & 75.00 \\
\hline French legal origin (FLO) & 39 & 0.64 & 0.49 & 0.00 & 1.00 \\
\hline Catholicism (CAT) & 39 & 0.23 & 0.43 & 0.00 & 1.00 \\
\hline Islam (Islam) & 39 & 0.31 & 0.47 & 0.00 & 1.00 \\
\hline Other religions (OTHR) & 39 & 0.38 & 0.49 & 0.00 & 1.00 \\
\hline Malaria stability index (MSI) ${ }^{+}$ & 39 & 11.20 & 8.57 & 0.00 & 31.55 \\
\hline Ethnic fractionalisation index $(\mathrm{EF})^{+}$ & 39 & 0.67 & 0.22 & 0.06 & 0.93 \\
\hline GDP per capita (GCAP) & 39 & 7.87 & 0.96 & 6.41 & 9.73 \\
\hline Inflation (INFL)* & 39 & 8.44 & 5.76 & 0.09 & 27.21 \\
\hline WG political stability $(\mathrm{PS})^{+}$ & 39 & -0.45 & 0.84 & -2.16 & 0.98 \\
\hline Population density $(\mathrm{PD})^{\#}$ & 39 & 78.48 & 111.37 & 2.59 & 625.92 \\
\hline WG control of corruption $(\mathrm{CC})^{+}$ & 39 & -0.56 & 0.57 & -1.36 & 0.96 \\
\hline Trade openness $(\mathrm{TO})^{*}$ & 39 & 78.18 & 28.45 & 34.29 & 164.93 \\
\hline
\end{tabular}

Notes

For a description of the variables and their sources see Table 1.

* In percentage terms; ${ }^{+}$in units; in natural logarithms of GDP per capita at PPP in constant 2011 international dollars; ${ }^{*}$ in numbers of people per square $\mathrm{km}$ of land area.

All other variables are dummies.

financial system development. ${ }^{16}$ The relatively exogenous nature of the historical institutional variables should reduce reverse causality concerns between the financial system development variables and the historical institutional variables. Moreover, the use of control variables should reduce omitted variable bias concerns in the models. The main summary statistics for the variables presented in this section are provided in Table 2, while Table 3 reports the correlation matrix.

\section{Results}

Estimation results are presented in Tables 4 to 7 . All estimations have been carried out using heteroscedasticity robust standard errors. Looking at Table 4,

16 OLS are an appropriate modelling choice because the averaged data is in cross-sectional form and the key explanatory variables can be considered as relatively exogenous determinants of the dependent variables (Alesina et al., 2003; La Porta et al., 1999; Wooldridge, 2009). Previous studies in this line of literature have also used OLS even when, as is the case in the present paper, the dependent variable is expressed as a percentage or proportional form (e.g. Beck et al., 2003; Djankov et al., 2007). 
Table 3. Pairwise correlation matrix

\begin{tabular}{|c|c|c|c|c|c|c|c|c|c|c|c|c|c|c|c|c|}
\hline & DMB & DMBOFI & FWLOC & FWAFMC & FLO & MSI & CAT & ISLAM & OTHR & $\mathrm{EF}$ & GCAP & INFL & PS & PD & $\mathrm{CC}$ & TO \\
\hline DMB & 1.00 & & & & & & & & & & & & & & & \\
\hline DMBOFI & $0.92^{*}$ & 1.00 & & & & & & & & & & & & & & \\
\hline FWAFMC & $-0.42^{*}$ & $-0.46^{*}$ & -0.09 & 1.00 & & & & & & & & & & & & \\
\hline FLO & -0.05 & -0.13 & -0.02 & $0.45^{*}$ & 1.00 & & & & & & & & & & & \\
\hline MSI & $-0.39^{*}$ & $-0.39^{*}$ & -0.24 & $0.64^{*}$ & 0.22 & 1.00 & & & & & & & & & & \\
\hline CAT & -0.19 & -0.17 & -0.01 & -0.03 & 0.16 & -0.24 & 1.00 & & & & & & & & & \\
\hline ISLAM & 0.01 & -0.04 & -0.21 & 0.01 & 0.15 & 0.16 & $-0.37^{*}$ & 1.00 & & & & & & & & \\
\hline OTHR & 0.14 & 0.19 & 0.11 & 0.10 & -0.18 & 0.09 & $-0.43^{*}$ & $-0.53^{*}$ & 1.00 & & & & & & & \\
\hline $\mathrm{EF}$ & $-0.36^{*}$ & -0.24 & $-0.39^{*}$ & $0.32^{*}$ & 0.04 & $0.49^{*}$ & 0.01 & -0.10 & 0.05 & 1.00 & & & & & & \\
\hline GCAP & $0.58^{*}$ & $0.52^{*}$ & 0.12 & $-0.53^{*}$ & -0.08 & $-0.40^{*}$ & 0.03 & 0.02 & 0.03 & $-0.39^{*}$ & 1.00 & & & & & \\
\hline INFL & -0.21 & -0.16 & $-0.39^{*}$ & 0.07 & $-0.33^{*}$ & 0.03 & 0.09 & -0.01 & 0.00 & 0.04 & 0.03 & 1.00 & & & & \\
\hline PS & $0.39^{*}$ & $0.32^{*}$ & $0.41^{*}$ & $-0.39^{*}$ & -0.26 & -0.20 & -0.07 & $-0.30^{*}$ & $0.32^{*}$ & -0.26 & $0.37^{*}$ & -0.25 & 1.00 & & & \\
\hline PD & $0.43^{*}$ & $0.29^{*}$ & $0.38^{*}$ & 0.08 & -0.02 & -0.12 & 0.05 & -0.13 & 0.12 & -0.24 & 0.07 & 0.03 & 0.10 & 1.00 & & \\
\hline $\mathrm{CC}$ & $0.62 *$ & $0.54^{*}$ & $0.58^{*}$ & $-0.43^{*}$ & $-0.32^{*}$ & $-0.34^{*}$ & -0.19 & -0.16 & 0.25 & $-0.50^{*}$ & $0.47^{*}$ & -0.12 & $0.74^{*}$ & 0.22 & 1.00 & \\
\hline
\end{tabular}

Note: For a description of the variables and their main summary statistics see Table 1 and Table 2 respectively.

${ }^{*}$ Significant at $10 \%$. 
Table 4. The impact of historical institutional variables on financial system depth (DMB)

\begin{tabular}{|c|c|c|c|c|c|}
\hline \multicolumn{6}{|c|}{ Dependent variable: Private credit by deposit banks on GDP (DMB) } \\
\hline & MOD1 & MOD2 & MOD3 & MOD4 & MOD5 \\
\hline French legal origin & $\begin{array}{r}-1.75 \\
6.20\end{array}$ & & & & \\
\hline Malaria stability index & & $\begin{array}{c}-0.84^{* *} \\
0.34\end{array}$ & & & $\begin{array}{c}-0.31 \\
(0.25)\end{array}$ \\
\hline Catholicism & & & $\begin{array}{r}-7.21 \\
12.15\end{array}$ & & \\
\hline Islam & & & $\begin{array}{r}-0.51 \\
12.13\end{array}$ & & \\
\hline Other religions & & & $\begin{array}{r}2.53 \\
12.45\end{array}$ & & \\
\hline Ethnic fractionalisation index & & & & $\begin{array}{c}-31.19^{* *} \\
13.68\end{array}$ & $\begin{array}{c}10.69 \\
(12.19)\end{array}$ \\
\hline GDP per capita & & & & & $\begin{array}{l}8.52^{* * *} \\
(2.88)\end{array}$ \\
\hline Inflation & & & & & $\begin{array}{c}-0.71^{* * *} \\
(0.26)\end{array}$ \\
\hline WG political stability & & & & & $\begin{array}{c}-4.28 \\
(3.29)\end{array}$ \\
\hline Population density & & & & & $\begin{array}{l}0.06^{* * *} \\
(0.01)\end{array}$ \\
\hline WG control of corruption & & & & & $\begin{array}{l}16.82^{* *} \\
(7.15)\end{array}$ \\
\hline Trade openness & & & & & $\begin{array}{c}-0.08 \\
(0.07)\end{array}$ \\
\hline Number of countries & 39 & 39 & 39 & 39 & 39 \\
\hline$R$-squared & 0.00 & 0.15 & 0.04 & 0.13 & 0.67 \\
\hline F-statistic & 0.0800 & 6.321 & 0.596 & 5.198 & 32.07 \\
\hline$P$-value of $F$-statistic & 0.779 & 0.0164 & 0.622 & 0.0285 & 0.000 \\
\hline
\end{tabular}

Notes

For a description of the variables see Table 1.

Robust standard errors in italics and brackets.

All regressions include the constant term.

The omitted legal origin is the English legal origin.

The omitted religion is Protestantism.

***, ${ }^{*}, *$ indicate significance at the $1 \%, 5 \%$ and $10 \%$ levels respectively.

when DMB, a measure of financial system depth, is used as dependent variable and the four theories of historical institutional determinants of financial system development are tested individually in MOD1 to MOD4, only the malaria stability index (MSI) and the ethnic fractionalisation index (EF) are statistically significant. As expected, both these variables seem to have a negative effect on DMB. However, when both MSI and EF are jointly included in the model along with the battery of chosen control variables (see Section 3.3), they lose statistical significance. Hence, considered overall, the results reported in Table 4 indicate 
Table 5. The impact of historical institutional variables on financial system depth (DMBOFI)

\begin{tabular}{|c|c|c|c|c|c|}
\hline \multicolumn{6}{|c|}{ Dependent variable: Private credit by deposit banks and other financial companies on GDP (DMBOFI) } \\
\hline & MOD1 & MOD2 & MOD3 & MOD4 & MOD5 \\
\hline French legal origin & $\begin{array}{r}-6.88 \\
10.23\end{array}$ & & & & \\
\hline Malaria stability index & & $\begin{array}{c}-1.13^{* *} \\
0.52\end{array}$ & & & $\begin{array}{r}-0.66 \\
(0.51)\end{array}$ \\
\hline Catholicism & & & $\begin{array}{r}-7.40 \\
12.04\end{array}$ & & \\
\hline Islam & & & $\begin{array}{r}-0.66 \\
12.04\end{array}$ & & \\
\hline Other religions & & & $\begin{array}{r}7.04 \\
14.55\end{array}$ & & \\
\hline Ethnic fractionalisation index & & & & $\begin{array}{c}-28.73^{*} \\
14.92\end{array}$ & $\begin{array}{c}27.23 \\
(26.09)\end{array}$ \\
\hline GDP per capita & & & & & $\begin{array}{l}11.80^{* *} \\
(5.22)\end{array}$ \\
\hline Inflation & & & & & $\begin{array}{c}-0.76^{* *} \\
(0.28)\end{array}$ \\
\hline WG political stability & & & & & $\begin{array}{c}-6.88 \\
(5.30)\end{array}$ \\
\hline Population density & & & & & $\begin{array}{c}0.05^{* *} \\
(0.02)\end{array}$ \\
\hline WG control of corruption & & & & & $\begin{array}{c}24.39^{*} \\
(13.54)\end{array}$ \\
\hline Trade openness & & & & & $\begin{array}{c}-0.18 \\
(0.13)\end{array}$ \\
\hline Number of countries & 39 & 39 & 39 & 39 & 39 \\
\hline$R$-squared & 0.02 & 0.14 & 0.05 & 0.06 & 0.54 \\
\hline$F$-statistic & 0.452 & 4.613 & 0.696 & 3.705 & 17.34 \\
\hline$P$-value of $F$-statistic & 0.506 & 0.0384 & 0.561 & 0.0620 & 0.000 \\
\hline
\end{tabular}

Notes

For a description of the variables see Table 1 .

Robust standard errors in italics and brackets.

All regressions include the constant term.

The omitted legal origin is the English legal origin.

The omitted religion is Protestantism.

$* * *, * *, *$ indicate significance at the $1 \%, 5 \%$ and $10 \%$ levels respectively

that the legal origins theory, the disease endowment theory, the religion-based theory and the ethnic fractionalisation theory do not explain variation in financial system depth in the African context.

Moving now to the results obtained when the dependent variable is DMBOFI, another measure of financial system depth, Table 5 reveals a similar qualitative picture to the one just discussed. In essence, the malaria stability index and ethnic fractionalisation index are statistically significant when entered alone (MOD2 and MOD4 respectively), but when they are put together in the same model 
Table 6. The impact of historical institutional variables on financial system access (FWLOC)

\begin{tabular}{|c|c|c|c|c|c|}
\hline \multicolumn{6}{|c|}{ Dependent variable: Firms with a bank loan or line of credit (FWLOC) } \\
\hline & MOD1 & MOD2 & MOD3 & MOD4 & MOD5 \\
\hline French legal origin & $\begin{array}{r}-0.58 \\
3.74\end{array}$ & & & & \\
\hline Malaria stability index & & $\begin{array}{r}-0.33 \\
0.20\end{array}$ & & & \\
\hline Catholicism & & & $\begin{array}{r}-7.64 \\
6.50\end{array}$ & & $\begin{array}{c}0.64 \\
(6.49)\end{array}$ \\
\hline Islam & & & $\begin{array}{c}-11.20^{* *} \\
5.35\end{array}$ & & $\begin{array}{r}-6.09 \\
(6.31)\end{array}$ \\
\hline Other religions & & & $\begin{array}{r}-5.75 \\
5.44\end{array}$ & & $\begin{array}{c}-3.50 \\
(6.25)\end{array}$ \\
\hline Ethnic fractionalisation index & & & & $\begin{array}{c}-22.22^{* *} \\
9.30\end{array}$ & $\begin{array}{r}-11.86^{*} \\
(6.97)\end{array}$ \\
\hline GDP per capita & & & & & $\begin{array}{c}-1.42 \\
(1.63)\end{array}$ \\
\hline Inflation & & & & & $\begin{array}{c}-0.70^{* * * *} \\
(0.23)\end{array}$ \\
\hline WG political stability & & & & & $\begin{array}{c}-1.38 \\
(2.62)\end{array}$ \\
\hline Population density & & & & & $\begin{array}{l}0.02^{* * *} \\
(0.01)\end{array}$ \\
\hline WG control of corruption & & & & & $\begin{array}{l}12.28^{* * *} \\
(3.49)\end{array}$ \\
\hline Trade openness & & & & & $\begin{array}{c}-0.09 \\
(0.05)\end{array}$ \\
\hline Number of countries & 39 & 39 & 39 & 39 & 39 \\
\hline$R$-squared & 0.00 & 0.06 & 0.07 & 0.16 & 0.61 \\
\hline$F$-statistic & 0.0242 & 2.742 & 1.526 & 5.714 & 29.24 \\
\hline$P$-value of $F$-statistic & 0.877 & 0.106 & 0.225 & 0.0220 & 0.000 \\
\hline
\end{tabular}

Notes

For a description of the variables see Table 1.

Robust standard errors in italics and brackets.

All regressions include the constant term.

The omitted legal origin is the English legal origin.

The omitted religion is Protestantism.

${ }^{* * *},{ }^{* *},{ }^{*}$ indicate significance at the $1 \%, 5 \%$ and $10 \%$ levels respectively.

with the control variables they are no longer statistically significant (MOD5). Consequently, none of the historical institutional variables seems to explain variation in financial system depth in the African context.

Turning now to evaluate whether the historical institutional variables explain variation in measures of access to financial systems, when FWLOC is used as a measure of financial system access (Table 6), only Islam and the ethnic fractionalisation index are statistically significant and appear to have a detrimental effect on financial system development when taken individually 
Table 7. The impact of historical institutional variables on financial system access (FWAFMC)

\begin{tabular}{|c|c|c|c|c|c|}
\hline \multicolumn{6}{|c|}{ Dependent variable: Firms with finance constraints (FWAFMC) } \\
\hline & MOD1 & MOD2 & MOD3 & MOD4 & MOD5 \\
\hline \multirow[t]{2}{*}{ French legal origin } & $13.56^{* * *}$ & & & & $11.37^{* * *}$ \\
\hline & 4.56 & & & & $(3.07)$ \\
\hline \multirow[t]{2}{*}{ Malaria stability index } & & $1.10^{* * *}$ & & & $0.76^{* * *}$ \\
\hline & & 0.19 & & & $(0.23)$ \\
\hline \multirow[t]{2}{*}{ Catholicism } & & & 6.87 & & \\
\hline & & & 9.62 & & \\
\hline \multirow[t]{2}{*}{ Islam } & & & 8.00 & & \\
\hline & & & 9.23 & & \\
\hline \multirow[t]{2}{*}{ Other religions } & & & 9.45 & & \\
\hline & & & 10.05 & & \\
\hline \multirow[t]{2}{*}{ Ethnic fractionalisation index } & & & & $21.95^{* * *}$ & -0.94 \\
\hline & & & & 7.11 & (9.14) \\
\hline \multirow[t]{2}{*}{ GDP per capita } & & & & & $-5.00^{* *}$ \\
\hline & & & & & $(1.83)$ \\
\hline \multirow[t]{2}{*}{ Inflation } & & & & & 0.44 \\
\hline & & & & & $(0.32)$ \\
\hline \multirow[t]{2}{*}{ WG political stability } & & & & & -1.65 \\
\hline & & & & & $(3.57)$ \\
\hline \multirow[t]{2}{*}{ Population density } & & & & & $0.02^{* *}$ \\
\hline & & & & & $(0.01)$ \\
\hline \multirow[t]{2}{*}{ WG control of corruption } & & & & & 1.45 \\
\hline & & & & & $(5.16)$ \\
\hline \multirow[t]{2}{*}{ Trade openness } & & & & & -0.01 \\
\hline & & & & & $(0.06)$ \\
\hline Number of countries & 39 & 39 & 39 & 39 & 39 \\
\hline$R$-squared & 0.20 & 0.42 & 0.03 & 0.10 & 0.67 \\
\hline F-statistic & 8.827 & 32.13 & 0.314 & 9.519 & 9.085 \\
\hline$P$-value of $F$-statistic & 0.00519 & 0.000 & 0.815 & 0.00384 & 0.000 \\
\hline
\end{tabular}

Notes

For a description of the variables see Table 1 .

Robust standard errors in italics and brackets.

All regressions include the constant term.

The omitted legal origin is the English legal origin.

The omitted religion is Protestantism.

$* * *, * *, *$ indicate significance at the $1 \%, 5 \%$ and $10 \%$ levels respectively.

(MOD3 and MOD4 respectively), but when they are considered along with the vector of control variables only the ethnic fractionalisation index remains statistically significant (MOD5). Hence the ethnic fractionalisation theory receives empirical support with this measure of financial system access.

As far as the results obtained for the model of historical institutional determinants of financial system development are concerned, when they are proxied by the second chosen measure of financial system access, namely 
FWAFMC, ${ }^{17}$ MOD1 to MOD4 in Table 7 show that the coefficients of French legal origin, the malaria stability index and the ethnic fractionalisation index are statistically significant and have a positive effect on FWAFMC, hence leading to lower levels of financial system development in African countries. When these statistically significant variables, and the set of control variables, are included in the same model (MOD5 in Table 7), only the coefficients of French legal origin and malaria stability index remain statistically significant and with the expected sign. Consequently the legal origins theory and the disease endowment theory are supported in this measure of financial system access, while the other theories do not receive empirical support.

A potential issue in the regression results is the possible endogeneity of the income and inflation controls. Although these two variables are standard controls in related studies (e.g. Brown et al. 2009; Djankov et al., 2007; Djankov et al., 2008 , among others), as a way of checking the extent to which their inclusion alters the results, all regressions have been rerun by removing these two control variables from the empirical models. The estimates thus obtained (not reported but available upon request) show that the qualitative picture of the results remains unchanged.

\section{Discussion and conclusion}

This paper empirically investigated the historical institutional determinants of cross-country variation in financial system development in Africa. The analysis, based on a sample of 39 former European colonies in Africa, produced the following results. First, using measures of financial system depth as proxies of financial system development, none of the four theories proposed in the literature on the topic (namely, legal origins theory, disease endowment theory, religionbased theory and ethnic fractionalisation theory) received empirical support. Second, empirical support is found for the ethnic fractionalisation theory when financial system access is measured with firms having a bank loan or line of credit. Finally, the legal origins theory and the disease endowment theory are supported in the data when financial system access is measured as a proportion of firms with finance constraints.

The above findings suggest that although historical institutional factors may not matter for financial system depth within the African context, they seem to matter for financial system access. A possible explanation for this finding is that financial system depth measures may be primarily driven by a few large and highly connected firms that do not depend necessarily on well-developed current institutional factors with strong historical links to obtain credit for their operations. Financial system access measures, instead, are primarily about

17 As discussed in Section 3.1, higher levels of FWAFMC imply lower levels of financial system development. 
access to finance by many more firms, especially SMEs, that are riskier and hence lenders may consider better developed current institutional factors with stronger historical dependence in their credit decisions. Consequently, historical institutional factors appear to have stronger effects on this dimension of financial system development than on depth measures. This suggests that to gain a better understanding of the determinants of financial system development, researchers should take into account access to finance measures of financial system development in addition to size measures.

The finding that legal origin is not a determinant of financial system depth is mostly in agreement with the results of Beck et al. (2003) and Fowowe (2014). This paper extends these earlier works by showing that legal origins explain cross-country variation in one of the financial system access measures within the African context, thus suggesting that this theory still has some value as a historical institutional explanation of cross-country variation in financial system development within the African context.

The above results have policy implications. Policy makers need to be aware that in Africa current poor financial system access may have links with detrimental institutional structures inherited from colonial times. Hence, the design of policies aimed at improving financial system development in African countries needs to take into account that path dependence and institutional complementarity effects are likely to impact on the outcome of such reforms.

This study is not without limitations. For one, the results are based on observed relationships that are partial correlations, consequently limiting strong causal interpretations. Future research in this area of enquiry would benefit from using case studies and historical narratives, which may help increase the causal interpretation of the links between dependent and key explanatory variables.

An avenue for future research is to identify the current legal rules and regulations that may act as institutional channels through which legal origins, malaria burden, religion and ethnic fractionalisation matter to financial system development within the African context. Identifying these current institutional channels can enable a better understanding of the processes through which the historical institutional factors exert their long-term effects and this may bring about a significant contribution in terms of policy design. Future work could also verify the results obtained in this study for other geographical areas, such as Latin America and the Caribbean, Central, East and South East Asia.

Overall considered, the evidence gathered in this article points to the need for more fine-grained theories and empirical measures that can provide robust explanations for cross-country variation in financial system development in Africa. 


\section{Acknowledgements}

We are grateful to Antoine Parent and two anonymous referees for their valuable comments and suggestions on earlier versions of the paper. We also thank Minna Paunova and participants at the 2nd World Interdisciplinary Network for Institutional Research (WINIR) Conference (Rio de Janeiro, Brazil, 2015). All remaining errors and omissions are our own.

\section{References}

Acemoglu, D., S. Johnson and J. A. Robinson (2001), 'The Colonial Origins of Comparative Development: An Empirical Investigation', American Economic Review 91(5): 1369401.

Acemoglu, D., S. Johnson and J. A. Robinson (2002), 'Reversal of Fortune: Geography and Institutions in the Making of the Modern World Income Distribution', Quarterly Journal of Economics, 117(4): 1231-94.

Alesina, A., A. Devleeschauwer, W. Easterly, S. Kurlat and R. Wacziarg (2003), 'Fractionalization', Journal of Economic Growth 8(2): 155-94.

Andersen, T. B., S. Jones and F. Tarp (2012), 'The Finance-Growth Thesis: A Sceptical Assessment', Journal of African Economies 21(supplementary 1): i57-i88.

Arcand, J. L., E. Berkes and U. Panizza (2015), ‘Too Much Finance?’ Journal of Economic Growth 20(2): 105-48.

Armour, J., S. Deakin, P. Lele and M. Siems (2009), 'How Do Legal Rules Evolve? Evidence from a Cross-Country Comparison of Shareholder, Creditor, and Worker Protection', American Journal of Comparative Law, 57(3): 579-629.

Armour, J., S. Deakin, V. Mollica and M. Siems (2009), 'Law and Financial Development: What we are Learning from Time-Series Evidence', BYU Law Review2009(6): 1435500 .

Armour, J., S. Deakin, P. Sarkar, M. Siems and A. Singh (2009), 'Shareholder Protection and Stock Market Development: An Empirical Test of the Legal Origins Hypothesis', Journal of Empirical Legal Studies 6(2): 343-80.

Arrunada, B. (2010), 'Protestants and Catholics: Similar Work Ethic, Different Social Ethic', Economic Journal 120(547): 890-918.

Ayyagari, M., A. Demirguc-Kunt and V. Maksimovic (2008a), 'How Important are Financing Constraints? The Role of Finance in the Business Environment', World Bank Economic Review 22(3): 483-516.

Ayyagari, M., A. Demirguc-Kunt and V. Maksimovic (2008b), 'How Well Do Institutional Theories Explain Firms' Perceptions of Property Rights?' Review of Financial Studies 21(4): 1833-71.

Beck, T. (2013), 'Finance, Growth, and Fragility: The Role of Government', International Journal of Banking, Accounting and Finance 5(1/2): 49-77.

Beck, T., H. Degryse and C. Kneer (2014), 'Is More Finance Better? Disentangling Intermediation and Size Effects of Financial Systems', Journal of Financial Stability 10(0): 50-64.

Beck, T. and A. Demirguc-Kunt (2006), 'Small and Medium-Size Enterprises: Access to Finance as a Growth Constraint', Journal of Banking \& Finance 30(11): 2931-43.

Beck, T., A. Demirguc-Kunt and R. Levine (2003), 'Law, Endowments, and Finance', Journal of Financial Economics 70(2): 137-81. 
Beck, T., A. Demirguc-Kunt, and R. Levine (2007), 'Finance, Inequality and the Poor', Journal of Economic Growth 12(1): 27-49.

Beck, T., A. Demirguc-Kunt and R. Levine (2010), 'Financial Institutions and Markets across Countries and Over Time: The Updated Financial Development and Structure Database', World Bank Economic Review 24(1): 77-92.

Beck, T., A. Demirguc-Kunt and R. Levine (2013), 'A Database on Financial Development and Structure', Retrieved from https://go.worldbank.org/X23UD9QUX0. Accessed October 2014.

Beck, T., A. Demirguc-Kunt and V. Maksimovic (2005), 'Financial and Legal Constraints to Growth: Does Firm Size Matter?’ Journal of Finance 60(1): pp. 137-77.

Beck, T., A. Demirguc-Kunt and V. Maksimovic (2006), 'The Influence of Financial and Legal Institutions on Firm Size', Journal of Banking \& Finance 30(11): 2995-3015.

Beck, T., A. Demirguc-Kunt and V. Maksimovic (2008), 'Financing Patterns around the World: Are Small Firms Different?' Journal of Financial Economics 89(3): 467-87.

Beck, T. and R. Levine (2005), 'Legal Institutions and Financial Development', In C. Menard and M. Shirley (eds), Handbook of New Institutional Economics The Netherlands: Springer, pp. 251-78.

Beck, T., S. M. Maimbo, I. Faye and T. Triki (2011), Financing Africa: Through the Crisis and Beyond, Washington, DC: International Bank for Reconstruction and Development/World Bank.

Brown, M., T. Jappelli, and M. Pagano (2009), 'Information Sharing and Credit: Firm-Level Evidence from Transition Countries', Journal of Financial Intermediation 18(2): 15172.

Carr, J. L. and J. T. Landa (1983), 'The Economics of Symbols, Clan Names, and Religion', Journal of Legal Studies 12(1): 135-56.

Carstensen, K. and E. Gundlach (2006), 'The Primacy of Institutions Reconsidered: Direct Income Effects of Malaria Prevalence', World Bank Economic Review 20(3): 309-39.

Cihak, M., A. Demirguc-Kunt, E. Feyen and R. Levine (2013), 'Financial Development in 205 Economies, 1960 to 2010', Journal of Financial Perspectives 1(2): 1-19.

Cooter, R. D. and J. T. Landa (1984), 'Personal Versus Impersonal Trade: The Size of Trading Groups and Contract Law', International Review of Law and Economics 4: 15-22.

Demirguc-Kunt, A., I. Love and V. Maksimovic (2006), 'Business Environment and the Incorporation Decision', Journal of Banking \& Finance 30(11): 2967-93.

Djankov, S., O. Hart, C. McLiesh, and A. Shleifer (2008), 'Debt Enforcement Around the World', Journal of Political Economy 116(6): 1105-49.

Djankov, S., C. McLiesh and A. Shleifer (2007), 'Private Credit in 129 Countries', Journal of Financial Economics 84(2): 299-329.

Easterly, W. and R. Levine (1997), 'Africa's Growth Tragedy: Policies and Ethnic Divisions', Quarterly Journal of Economics 112(4): 1203-50.

Easterly, W., J. Ritzen and M. Woolcock (2006), 'Social Cohesion, Institutions, and Growth', Economics \& Politics 18(2): 103-20.

Fowowe, B. (2014), 'Law and Finance Revisited: Evidence from African Countries', South African Journal of Economics 82(2): 193-208.

Fox, J. (2006), 'World Separation of Religion and State into the 21st Century', Comparative Political Studies 39(5): 537-69.

Gennaioli, N., R. La Porta, F. Lopez-de-Silanes and A. Shleifer (2014), 'Growth in Regions', Journal of Economic Growth 19(3): 259-309. 
Greif, A. (1992), 'Institutions and International Trade: Lessons from the Commercial Revolution', American Economic Review 82(2): 128-33.

Greif, A. (1993), 'Contract Enforceability and Economic Institutions in Early Trade: The Maghribi Traders' Coalition', American Economic Review 83(3): 525-48.

Greif, A., P. Milgrom and B. R. Weingast (1994), 'Coordination, Commitment, and Enforcement: The Case of the Merchant Guild', Journal of Political Economy 102(4): 745-76.

Gries, T., M. Kraft and D. Meierrieks (2009), 'Linkages between Financial Deepening, Trade Openness, and Economic Development: Causality Evidence from Sub-Saharan Africa', World Development 37(12): 1849-60.

Hamori, S., and Y. Hashiguchi (2012), 'The Effect of Financial Deepening on Inequality: Some International Evidence', Journal of Asian Economics, 23(4): 353-9.

Honohan, P. and T. Beck (2007), Making Finance Work for Africa, Washington, DC: World Bank.

Kaufmann, D., A. Kraay and M. Mastruzzi (2010), The Worldwide Governance Indicators: Methodology and Analytical Issues. World Bank Policy Research Working Paper No. 5430. The World Bank Development Research Group Macroeconomics and Growth Team. Retrieved from http://ssrn.com/abstract=1682130. Accessed January 2017.

Kiszewski, A., A. Mellinger, A. Spielman, P. Malaney, S. E. Sachs and J. D. Sachs (2004), 'A Global Index Representing the Stability of Malaria Transmission', American Journal of Tropical Medicine and Hygiene 70(5): 486-98.

La Porta, R., F. Lopez-de-Silanes and A. Shleifer (2008a), Dataset for the Paper: 'The Economic Consequences of Legal Origins', retrieved from http://www.economics.harvard.edu/faculty/shleifer/dataset. Accessed January 2012.

La Porta, R., F. Lopez-de-Silanes and A. Shleifer (2008b), 'The Economic Consequences of Legal Origins', Journal of Economic Literature 46(2): 285-332.

La Porta, R., F. Lopez-De-Silanes, A. Shleifer and R. W. Vishny (1997), 'Legal Determinants of External Finance', Journal of Finance 52(3): 1131-50.

La Porta, R., F. Lopez-de-Silanes, A. Shleifer and R. W. Vishny (1998), 'Law and Finance', Journal of Political Economy 106(6): 1113-55.

La Porta, R., F. Lopez-de-Silanes, A. Shleifer and R. W. Vishny (1999), 'The Quality of Government', Journal of Law, Economics, and Organization 15(1): 222-79.

Landa, J. T. (1981), 'A Theory of the Ethnically Homogeneous Middleman Group: An Institutional Alternative to Contract Law', Journal of Legal Studies 10(2): 349-62.

Levine, R. (2005), 'Finance and Growth: Theory and Evidence', in P. Aghion and S. N. Durlauf (eds), Handbook of Economic Growth, Volume 1, Part 1, The Netherlands: Elsevier B. V., pp. 865-934.

McCleary, R. M. and R. J. Barro (2006), 'Religion and Economy', Journal of Economic Perspectives 20(2): 49-72.

McCord, G. C. (2012), 'A Global Index Representing the Stability of Malaria Transmission Country-Level Dataset', retrieved from https://sites.google.com/site/ gordoncmccord/datasets. Accessed October 2012.

Murinde, V. (2012), 'Financial Development and Economic Growth: Global and African Evidence', Journal of African Economies 21(supplementary 1): i10-i56.

Philpott, D. (2007), 'Explaining the Political Ambivalence of Religion', American Political Science Review 101(3): 505-25.

Pistor, K. (2009), 'Rethinking the "Law and Finance” Paradigm', BYU Law Review 2009(6): $1647-70$. 
Sachs, J. D. (2003), 'Institutions Don't Rule: Direct Effects of Geography on Per Capita Income', NBER Working Paper 9490, Cambridge, MA: National Bureau of Economic Research.

Sachs, J. D. and R. G. Chambers (2009), 'The New Global War on Malaria', in A. Clapham and M. Robinson (eds), Realizing the Right to Health, 3, Zurich: Ruffer \& Rub, pp. 305-23.

Samargandi, N., J. Fidrmuc and S. Ghosh (2015), 'Is the Relationship between Financial Development and Economic Growth Monotonic? Evidence from a Sample of MiddleIncome Countries', World Development 68(4): 66-81.

Siems, M. and S. Deakin (2010), 'Comparative Law and Finance: Past, Present, and Future Research', Journal of Institutional and Theoretical Economics 166(1): 120-40.

Spamann, H. (2010), 'The “Antidirector Rights Index” Revisited', Review of Financial Studies 23(2): 467-86.

Stulz, R. M. and R. Williamson (2003), 'Culture, Openness, and Finance', Journal of Financial Economics 70(3): 313-49.

Weber, M. (2005 [1930]), The Protestant Ethic and the Spirit of Capitalism (Taylor, \& Francis e-Library, ed.), New York, NY: Routledge.

Wooldridge, J. M. (2009), Introductory Econometrics: A Modern Approach, Florence, KY: South Western Cengage Learning.

World Bank (2012), Global Financial Development Report 2013: Rethinking the Role of the State in Finance, Washington, DC: World Bank.

World Bank (2013), Global Financial Development Database, Retrieved from http://go.worldbank.org/TC4IB7YOW0. Accessed October 2014.

World Bank (2014a), World Development Indicators, Retrieved from http://data.worldbank.org/data-catalog/world-development-indicators. Accessed October 2014.

World Bank (2014b), The Worldwide Governance Indicators (WGI) Project Dataset, Retrieved from http://info.worldbank.org/governance/wgi/index.aspx\#home. Accessed October 2014. 
Appendix 1. Sample countries with legal origins categorisation

\begin{tabular}{llll}
\hline \hline Country & Legal origin & Country & Legal origin \\
\hline Algeria & FLO & Lesotho & ELO \\
Angola & FLO & Madagascar & FLO \\
Benin & FLO & Malawi & ELO \\
Botswana & ELO & Mali & FLO \\
Burkina Faso & FLO & Mauritania & FLO \\
Burundi & FLO & Mauritius & FLO \\
Cameroon & FLO & Morocco & FLO \\
Cape Verde & FLO & Mozambique & FLO \\
Central African Republic & FLO & Namibia & ELO \\
Chad & FLO & Niger & FLO \\
Congo, Democratic Republic & FLO & Nigeria & ELO \\
Congo, Republic & FLO & Senegal & FLO \\
Cote d'Ivoire & FLO & Sierra Leone & ELO \\
Egypt, Arab Republic & FLO & South Africa & ELO \\
Gabon & FLO & Swaziland & ELO \\
Gambia & ELO & Tanzania & ELO \\
Ghana & ELO & Togo & FLO \\
Guinea & FLO & Uganda & ELO \\
Guinea-Bissau & FLO & Zambia & ELO \\
Kenya & ELO & & \\
\hline \hline
\end{tabular}

Notes

$\mathrm{FLO}=$ French legal origin categorisation; $\mathrm{ELO}=$ English legal origin categorisation. 